\title{
Participation under Compulsion
}

\author{
doi:10.3991/ijet.v5i4.1458 \\ P. Grell and F. Rau \\ University of Potsdam, Potsdam, Germany
}

\begin{abstract}
Benefits of Social Software in teaching and learning are a research subject of great interest, especially in higher education. Even though the opportunities to encourage students' participation are promising, there is a neglected area we intend to illuminate: heteronomy. Compulsion and external control are used to foster participation. In our study we examined 16 international evaluation and research papers which describe the implementation of Social Software to enhance students' participation within courses. Several contradictions within these descriptions were revealed. One may realise that students pretend to "play the game" due to assessment regulations. The tension between students' self-responsibility and external control in education needs to be reflected systematically.
\end{abstract}

Index Terms-Participation; Heteronomy; Resistance; Social Software; Higher Education

\section{INTRODUCTION}

Benefits of Social Software in teaching and learning are a topic of great interest, especially in higher education. We agree that it would be "foolish to ignore the tremendous opportunities" [16]. The possibilities to encourage students' participation are promising: enhancing autonomy and collaboration, sharing experiences, higher grades of participation, learning through peer review, instant feedback [7, 9].

Even though these possibilities appear to be promising to encourage students' participation, there is a neglected area we intend to point out: the tension between heteronomy and self-determination. Courses in higher education are subject to framework conditions. Unlike informal learning or leisure activities within social communities, students have to make decisions due to restricted time and intended outcome of their efforts (pass the exam, good marks). Often assigned collaboration becomes part of assessment. Teachers initiate the collaborative learning process by setting the rules. Due to the assessment criteria external control and compulsion become part of the learning environment. Theses (hidden) elements of external control within innovative and cooperative learning settings are neglected.

We think it is important to focus on the autonomyheteronomy-dilemma within courses using Social Software. The core of this study is an analysis and discussion of research and evaluation papers.

\section{EXEMPLARY OVERVIEW}

In order to provide an exemplary overview of the use and impact of Social Software and Web 2.0 tools on teaching and learning in higher education two different search approaches were conducted. In the first approach, we searched for journal articles which include in their title one of the terms „social software“, „Web 2.0“, „wiki”, "blog”, “microblog”, "eportfolio”, "collaborative learning”, "blogging”, "peer feedback” or "learning communities" and which were published between 2008 and 2010. The journals used for the literature search included "The Internet and Higher Education" and "Computer \& Education” (published by Elsevier) as well as the scientific Open Access journal "Future Internet” (published by MDPI). The second approach considered especially conference proceedings published since 2008 . Searches were made in the electronic database „ACM Digital Library“ using the keyword "education" and the same descriptors as before. Furthermore, we took the German speaking community into account by reviewing the proceedings from "GMW" and "DeLFI" 2009. On May 1st, 2010 the searches revealed a total of 105 articles. After excluding nonempirical papers and articles which were found to be unrelated to the use and impact of social software in higher education, the remaining 16 papers were identified for a more profound review.

TABLE I.

SUMMARY OF REVIEWED STUDIES

\begin{tabular}{|c|c|}
\hline Source & Context of social software \\
\hline $\begin{array}{l}\text { Ref. [1] Anderson } \\
\text { \& Lin (2009) }\end{array}$ & $\begin{array}{l}\text { A course blog was created to build an inclusive } \\
\text { collaborative learning community with the pur- } \\
\text { pose to connect students with diverse back- } \\
\text { grounds outside the classroom and foster their } \\
\text { learning. }\end{array}$ \\
\hline $\begin{array}{l}\text { Ref. [2] Bonk, } \\
\text { Lee, Kim \& Lin } \\
\text { (2009) }\end{array}$ & $\begin{array}{l}\text { Students participated in three cross institutional } \\
\text { wikibook projects. The didactical setting as well } \\
\text { as the degree of success differed in each project. }\end{array}$ \\
\hline $\begin{array}{l}\text { Ref. [3] Cole } \\
\text { (2009) }\end{array}$ & $\begin{array}{l}\text { It was sought to determine whether a wiki envi- } \\
\text { ronment could be used to support student en- } \\
\text { gagement and create a module level knowledge } \\
\text { repository. Several pedagogical changes were } \\
\text { made to integrate the wiki-activity. In additon, } \\
\text { the assessment structure was modified to encour- } \\
\text { age the students. }\end{array}$ \\
\hline $\begin{array}{l}\text { Ref. [4] Ebner \& } \\
\text { Maurer (2009) }\end{array}$ & $\begin{array}{l}\text { Students had to choose whether they wanted to } \\
\text { participate in a blogging or microblogging group } \\
\text { instead of using conventional methods. Blogger } \\
\text { were required to post two times a week. Microb- } \\
\text { logger had to post two microblogs a week and } \\
\text { comment two blog posts. }\end{array}$ \\
\hline $\begin{array}{l}\text { Ref. [5] Ebner, } \\
\text { Lienhardt, Rohs \& } \\
\text { Meyer (2010) }\end{array}$ & $\begin{array}{l}\text { After a short introduction of a wiki and a microb- } \\
\text { log students were expected to try out these tools } \\
\text { for the purpose of developing own strategies for } \\
\text { an effective use. Regular and frequent use of } \\
\text { these tools was obligatory in order to document } \\
\text { their learning activities. }\end{array}$ \\
\hline $\begin{array}{l}\text { Ref. [6] Ehlers, } \\
\text { Adelsberger \& } \\
\text { Teschler (2009) }\end{array}$ & $\begin{array}{l}\text { Students were required to reflect regularly their } \\
\text { working and learning progress in group blogs. } \\
\text { They were instructed to blog one time per week } \\
\text { and to peer review another group blog. Helpful } \\
\text { questions to reflect were given and the blogposts } \\
\text { were assessed for the course grade. }\end{array}$ \\
\hline
\end{tabular}




\begin{tabular}{|c|c|}
\hline Source & Context of social software \\
\hline $\begin{array}{l}\text { Ref. [8] Halic, } \\
\text { Lee, Paulus \& } \\
\text { Marscha (2010) }\end{array}$ & $\begin{array}{l}\text { Each student was required to blog and comment } \\
\text { one time per week within a group blog. They had } \\
\text { to discuss and reflect embedded articles and } \\
\text { videos. A graduate teaching assistant acted as } \\
\text { blog facilitator. }\end{array}$ \\
\hline $\begin{array}{l}\text { Ref. [10] Hermann } \\
\text { \& Janzen (2009) }\end{array}$ & $\begin{array}{l}\text { Students were assigned to create wiki pages to } \\
\text { predefined topics based on given lectures. They } \\
\text { were working in different groups under tutor } \\
\text { supervision using a specific wiki which was } \\
\text { linked to the corresponding eLecture. }\end{array}$ \\
\hline $\begin{array}{l}\text { Ref. [11] Meyer } \\
\text { (2010) }\end{array}$ & $\begin{array}{l}\text { In the first assignment participants were required } \\
\text { to develop wiki sites based on a review of data } \\
\text { and research in order to answer predefined ques- } \\
\text { tions. In the second approach students were as- } \\
\text { signed to post their individual findings within a } \\
\text { group blog. }\end{array}$ \\
\hline $\begin{array}{l}\text { Ref. [12] Öner } \\
\text { (2009) }\end{array}$ & $\begin{array}{l}\text { Pre-service teachers were required to work in } \\
\text { groups within a wiki environment to prepare two } \\
\text { lesson plans. In order to monitor the process of } \\
\text { group work, students were to record their contri- } \\
\text { butions after face-to-face meetings within the } \\
\text { wiki. }\end{array}$ \\
\hline $\begin{array}{l}\text { Ref. [13] Requena- } \\
\text { Carrión, } \\
\text { Rodríguez- } \\
\text { González, } \\
\text { Marques and } \\
\text { Gutiérrez-Pérez } \\
\text { (2009) } \\
\end{array}$ & $\begin{array}{l}\text { Students were instructed to create wiki-entries } \\
\text { under teacher supervision. The main aspects each } \\
\text { wiki-page should provide were predefined. En- } \\
\text { tries were assigned to groups of two to three } \\
\text { persons. Inter-group collaboration was encour- } \\
\text { aged. }\end{array}$ \\
\hline $\begin{array}{l}\text { Ref. [14] Safran } \\
\text { (2008) }\end{array}$ & $\begin{array}{l}\text { Students were assigned to different blogging and } \\
\text { non-blogging groups. Members of the blogging } \\
\text { group could voluntarily blog about their learning } \\
\text { progress. By blogging at least one time per week } \\
\text { students could earn additional points for their } \\
\text { course grade. }\end{array}$ \\
\hline $\begin{array}{l}\text { Ref. [15] Sarkar } \\
\text { (2009) }\end{array}$ & $\begin{array}{l}\text { Each student had to create a wiki-page based on } \\
\text { his notes of a lecture within one week. After that } \\
\text { the whole class was to modify this draft by edit- } \\
\text { ing and adding more content within another } \\
\text { week. The wiki assignments were worth } 20 \% \text { of } \\
\text { the course grade. }\end{array}$ \\
\hline $\begin{array}{l}\text { Ref. [16] Wheeler } \\
\text { (2009) }\end{array}$ & $\begin{array}{l}\text { In the first study students created their own blogs } \\
\text { and used a wiki to respond to several questions } \\
\text { given in the wiki. In the second study students } \\
\text { could use group blogs to share their progress in } \\
\text { their own research projects, to discuss and to } \\
\text { support each other socially. }\end{array}$ \\
\hline $\begin{array}{l}\text { Ref. [17] Xiao \& } \\
\text { Lucking (2008). }\end{array}$ & $\begin{array}{l}\text { Each Student got the assignment to write a } 1000- \\
\text { word article within a wikibook on one of sixty- } \\
\text { six possible topics. Students had to participate in } \\
\text { two rounds of peer assessment. The assignments } \\
\text { were worth } 35 \% \text { of the course grade. }\end{array}$ \\
\hline $\begin{array}{l}\text { Ref. [18] Xie, Ke } \\
\& \text { Sharma (2008) }\end{array}$ & $\begin{array}{l}\text { Students were required to keep reflective journals } \\
\text { by using a blog and post at least one time per } \\
\text { week. The assignment was worth } 10 \% \text { of the } \\
\text { course grade. Further students were randomly } \\
\text { assigned to two groups. The control group } \\
\text { blogged one semester without peer-feedback } \\
\text { while the treatment group blogged for one month } \\
\text { with peer-feedback. }\end{array}$ \\
\hline
\end{tabular}

\section{FINDINGS}

\section{A. Issues of participation}

Issues of participation were subject to discussion in almost two thirds of the investigated papers, but in very different ways. Some case studies mentioned a lack of students' participation in the course $[2,3,14]$ or at least in specific areas of it $[4,11,13]$. Conclusions and recom- mendations in other papers $[1,8]$ appear to be questionable due to the complete lack of attention to participation.

Some authors point out that optional assignments do not lead to engaged participation [2, 3, 14]. In Safran's case study [14] students were asked to blog on a voluntary basis. But less than $30 \%$ of the students decided to start a weblog. Cole describes an experiment with a wiki environment which failed due to a lack of student participation. Although several pedagogical changes were made, the wiki contained zero posts after five weeks [3]. Similarly, Bonk, Lee, Kim \& Lin report wikibook projects which suffered from minimal student participation and discuss “... the optional nature of the assignment" [2] as a possible reason for their experiences.

A lack of participation is mentioned in case studies even if teachers/researchers tried to enhance participation and collaboration through obligatory interactive parts of coursework. For example, Ebner \& Maurer intended to start discussions between blogger and reviewer by setting mandatory assignments: providing a minimum of two posts or comments a week. However, they found that peer feedback did not work in the intended way: "Although Weblogs are a kind of communication this did not really happen" [4]. These findings were similar to the results of Meyer's study [11]. While students blog about their findings based on given literature they did not attempt to comment each others work. Xie, Ke \& Sharma investigated the interaction effects of peer feedback and blogging on reflective thinking skills. Although blogging was mandatory, they were confronted with a high drop-out rate (38.6\%) [18]. Requena-Carrión, Rodríguez-González, Marques and Gutiérrez-Pérez point out that collaborative writing in a wiki worked within assigned groups but intergroup collaboration did not happen at all [13].

Participation is marginally mentioned by Halic, Lee, Paulus \& Marscha [8], Ebner, Lienhardt, Rohs \& Meyer [5], Anderson \& Lin [1] and Wheeler [16]. Halic, Lee, Paulus \& Marscha examined student perceptions of blog effectiveness for learning. Readers may be surprised when the authors point out at the end, that they did not "attempt to make comparisons between students who used blogs and those who did not" [8] and recommend that this be done in further research. It seems to be a questionable decision not to announce participation and drop-out during the case study. Ebner, Lienhardt, Rohs \& Meyer found that students may pretend to participate when they were forced by obligatory assignments: "students appeared to be 'playing the game' rather than using the tool for their own purposes" [5]. Anderson \& Lin consider the degree of student participation as a determinant for investigating different tools "to build an inclusive collaborative learning community” [1]. Surprisingly they hardly provide information about the educational setting related to the compared tools (blogs vs. user groups). Wheeler describes two case studies in which students offer their views about using social software within a course. Different reasons why students participate or why they refuse to do so were mentioned [16]. Unfortunately, it remains incomprehensible whether assignment relating to the use of the tools was mandatory or not.

\section{B. Trying to initiate participation without reflecting the consequences}

We identified several approaches where teachers/researchers try to initiate collaboration or participation 
within a social software environment. This takes different forms: While a few studies concentrate on basic scaffolding [3] or guidance [14, 16], many others provide learning environments with additional external control like incentives or assessment $[2,8,10,13,17]$. The majority of teachers/researchers try to overcome the lack of participation by focusing closely on extrinsic motivation or external control [4, 5, 6, 11, 12, 15, 18]. An interesting point is that some authors did not offer any explanations for their chosen course design [8, 10,11, 13, 14] although these could provide further insights into their findings. Furthermore, in most of the papers it has not been taken into consideration that the design of the course and the corresponding assignments may have had an influence on the outcome of the course itself as well as the results of the study.

The majority of the reviewed case studies tried to initiate participation by focusing closely on external control or extrinsic motivation in form of obligatory assignments or assessment [4, 5, 6, 11, 12, 15, 18]. For example, Ebner, Lienhardt, Rohs \& Meyer tried to initiate participation by making "regular and frequent use of MBlog and MediaWiki [...] obligatory from the start" [5]. But except for a short introduction they did not provide any kind of scaffolding or limitations on how to use these tools. Similarly, other studies provided educational settings with mandatory assignments and assessment but hardly any additional scaffolding [4, 11, 12]. Ebner \& Mauer offered a blogging/ microblogging environment in which students had to provide a minimum of two posts a week. These contributions were taken into account for the course grade [4]. Meyer required students to collaborate within a wiki to create two sites for a large amount of given publications. A "group grade" was provided with individual modifications. In her blog approach students got the obligatory assignment to "post their own findings based on specific reports” [11]. But guidance or scaffolding was not provided at all. Similarly, Öner pursues the "idea that less scaffolding would result in better end product” [12]. However, working in groups within a wiki was a mandatory requirement for this course and the wiki-based contributions counted for the course grade. In contrast, other studies provided - besides obligatory assignments - additional external scaffolding like due dates, guidelines or tutorials [6, 15, 18]. Ehlers, Adelsberger \& Teschler and Xie, Ke and Sharma provided different blogging environments to promote reflective journaling $[6,18]$. To facilitate this process they offered different journaling guidelines. But regular contributions as well as providing peer feedback were requirements in both courses. These contributions represented one part of the course grade. Sarkar tried to initiate participation by providing individual assignments as well as group assignments within a wikienvironment. Furthermore, "grading structure and due date were important do induce students to participate" [15].

Only two authors described course designs in which students' participation was promoted through basic scaffolding and guidance in contrast to using external control $[3,14]$. Cole made several pedagogical changes to transform a course into a blended learning design which embedded the wiki activity. Moreover "the wiki was created with basic instructional scaffolding and subsequently promoted through lectures” [3]. Safran provided an educational scenario "where the use of weblogs was enabled and encouraged but not compulsory” [14]. In order to encourage students' participation, mentoring tutors acted as blog facilitators and additional points to the course's assessment were offered to regularly blogging students.

In addition to guidance and scaffolding, several authors/researchers/teachers provided external control elements in order to initiate participation [8, 10, 13, 17]. Halic, Lee, Paulus \& Marscha used a setting in which every "student was required to submit one post and one comment per week for nine weeks on a blog shared within each discussion group” [8]. Guidance was provided by graduate teaching assistants who "acted as blog facilitators” [8]. Xiao \& Lucking gave the obligatory assignment to write an article in a wikibook and "to participate in two rounds of peer assessment exercises" [17]. These assignments were worth $35 \%$ of the course grade. The instructor provided assistance through feedback for each student. Requena-Carrión et al. as well as Hermann \& Janzen required students to work in groups to write two wikiarticles on predefined topics $[10,13]$. In order to facilitate this process, Hermann \& Janzen (2009) provided mentoring tutors and article structures while for Requena-Carrión et al. (2009) wiki entries were created "under teacher supervision" (p. 1). Thus a number of different forms to facilitate/promote participation were chosen in the presented studies.

To our surprise we identified several approaches to initiate participation in a course without any explanations given for the chosen attempt [8, 10, 11, 13, 14]. But an understanding of the decisions relating to course design is essential for the interpretation of the research results. Although some of the authors describe the meaning of collaboration for learning $[10,11,13]$ or made reference to constructivist learning theories $[8,14]$ within their preliminary considerations, they did not refer to these theories when they described their approach to initiate participation. Some studies did not make any statements about the didactical design of their course [1] or the assignment relating to the use of social software [16]. Other course designs were based on practical experiences of previous findings [3] or were partly justified by practical constraints $[5,12,18]$. The use of external control or the embedding of assessment issues was explained as additional encouragement [2, 14, 15] or extrinsic motivation [18]. Only a few approaches referred to preliminary didactical considerations $[4,6]$.

According to the papers the necessity of mandatory assignments or assessment sometimes seems inevitable in formal settings. But it is surprising that only a few papers $[2,3,4,5]$ consider the consequences relating to the use of external control in an educational setting. It is doubtful whether forcing students to participate due to obligatory assignments leads to what Wheeler calls "social construction” [16]. For example, Ebner, Lienhardt, Rohs \& Meyer found: „Although the volume of posts increased due to the obligatory use of the application, students appeared to be 'playing the game' rather than using the tool for their own purposes" [5].

\section{Reflecting the impact of non-voluntary participation and pressure}

Few papers reflect the issue of non-voluntary participation or the structures of the situation and its impact on the learning process. Bonk, Lee, Kim \& Lin reflect their experiences with wiki-book projects. They take a close look 
at the students' backgrounds, their expectations and their confusions in a knowledge construction and negotiation process [2]. They try to understand students' acting in an unknown learning situation, e.g. regarding that the grading model at the university is usually based on individual work. They point out the problems of not fully implementing voluntary participation and tensions arising through forced peer feedback [2]. They question the possibility to develop a community in a bounded university course and reflect their tactics to enable community building (p. 133). They reflect the degree of structure and task scaffolding built into the system. They discuss the embedding of incentives and its impact on intrinsic motivation. And even if their experiences are promising, they do not ignore the limitations of their project within a higher education course. "In effect, transformation at the highest level, wherein students become a collaborative community generating and evaluating each other's ideas and altering their own perspectives or viewpoints, typically did not occur. Instead, there was more of a guided learning experience with some instructor control and some student control, which impacted on the forms and types of collaboration experienced.” [2]

Cole takes a closer look at the students' points of view. She points out that factors outside the control of a teacher might have an impact on participation. "Students prioritise their time according to the greatest perceived benefit with the result that coursework deadlines for other modules and part-time work pressures are automatically awarded a higher priority" [3]. She reflects, what is often neglected, that lectures and students have different needs which have to be balanced. Her findings suggest "that for students, perceived usefulness is directly related to assessment structures" [3]. Cole emphasises that "education exists in a consumerist culture where altruistic acts are devalued and individual effort is rewarded" [3].

\section{DISCUSSION}

It is interesting, that the lack of participation within courses using blogs, wikis or similar tools is hardly discussed theoretically. Lack of participation appears in some case studies as if it were a problem that could be solved by means of some simple practical arrangements or incentives or could just be ignored.

These issues of participation in teaching and learning settings are well known in education. They are dealt with broadly within the discussion about self-directed learning in adult education. The main issue is that participation is based on interests and ownership. If a student is forced to do something which he is not interested in, he might adjust himself to ward off a threat. But this way of "playing the game" is neither a form of participation nor will it lead automatically to learning. It is a strategy to cope with the situation and is an adaptation to the "hidden curriculum". Students will use (other) strategies to pass the tests as well. Learners, understood as human beings with a free will and mind, use these strategies to act reasonably in a situation. That is one reason why educational and didactical scientists do not talk about "tools or tricks to motivate" students, but question the sense and the meaning of the situation and the chosen topics with a view to the learners' future lives. They question the teaching and learning environment from different perspectives. Learners' views and teachers' views of the situation, interaction and environment are different. From a subjective point of view the topics of teaching and learning are perceived as useful or not due to different current life situations and goals. A curriculum on the other hand is an attempt of experts in a certain time and culture to identify and focus on key issues for the next generation (of experts). And the experts' views will be different from the novices' views. The key problem or challenge in a teaching and learning environment that is based on self-direction and participation following constructivism, situated learning, pragmatism or similar contemporary theories of learning - is to balance these different interests. The fundamental question is: Is it possible to achieve participation, self-reliance, maturity and autonomy through control and heteronomy?

\section{REFERENCES}

[1] Anderson, N., \& Lin, C., (2009). Exploring technologies for building collaborative learning communities among diverse student populations. In Proceedings of the 14th Annual ACM SIGCSE Conference on innovation and Technology in Computer Science Education. New York, NY: ACM, 243-247.

[2] Bonk, C. J, Lee, M. M., Kim, N., \& Lin, M.-F. G. (2009). The tensions of transformation in three cross-institutional wikibook projects. The Internet and Higher Education, 12(3-4), 126-135. doi:10.1016/j.iheduc.2009.04.002

[3] Cole M. (2009). Using Wiki technology to support student engagement: Lessons from the trenches. Computers \& Education. 52(1), 141-146. doi:10.1016/j.compedu.2008.07.003

[4] Ebner M., \& Maurer H. (2009). Can Weblogs and Microblogs Change Traditional Scientific Writing?. Future Internet. 1(1), 4758. doi:10.3390/fi1010047

[5] Ebner, M., Lienhardt, C., Rohs, M., \& Meyer, I. (2010) Microblogs in Higher Education - A chance to facilitate informal and process-oriented learning?. Computers \& Education. 55(1), 92100. doi:10.1016/j.compedu.2009.12.006

[6] Ehlers, U.-D., Adelsberger, H.H., \& Teschler, S. (2009). Reflexion im Netz: Auf dem Weg zur Employability im Studium. In N. Apostolopoulos, H. Hoffmann, V. Mansmann \& A. Schwill (Hrsg.), E-Learning 2009. Lernen im digitalen Zeitalter. Münster: Waxmann Verlag, 15-29.

[7] Grosseck, G. (2009). To use or not to use web 2.0 in higher education? Procedia Social and Behavioral Sciences. 1, 478-482. doi:10.1016/j.sbspro.2009.01.087

[8] Halic, O., Lee, D., Paulus T., \& Spence Marsha (2010). To blog or not to blog: Student perceptions of blog effectiveness for learning in a college-level course. The Internet and Higher Education, In Press, Corrected Proof, Available online 14 April 2010, ISSN 1096-7516, DOI: 10.1016/j.iheduc.2010.04.001.

[9] Hardy, N., Pinto, M., \& Wei, H. (2008). The Impact of Collaborative Technology in IT and Computer Science Education: Harnessing the Power of Web 2.0. In Proceedings of the 9th ACM SIGITE conference on Information technology education. New York, NY: ACM, 63-64.

[10] Hermann, C. \& Janzen, A. (2009). Electures-Wiki - Aktive Nutzung von Vorlesungsaufzeichnungen. In A. Schwill \& N. Apostolopoulos (Hrsg.), Lernen im Digitalen Zeitalter. DeLFI 2009 - Die 7. E-Learning Fachtagung Informatik. Bonn: Köllen Druck+Verlag GmbH, 127-138.

[11] Meyer, K.A. (2010). A comparison of Web 2.0 tools in a doctoral course. The Internet and Higher Education, In Press, Corrected Proof, Available online 11 February 2010, ISSN 1096-7516, DOI: 10.1016/j.iheduc.2010.02.002.

[12] Öner, D. (2009). Pre-service teachers' experiences with Wiki: challenges of asynchronous collaboration. In Proceedings of the 5th international Symposium on Wikis and Open. WikiSym '09. New York, NY: ACM, 1-2.

[13] Requena-Carrión, J., Rodríguez-González, A. B., Marques, A. G., and Gutiérrez-Pérez, D. (2009). Work in progress - implantation of a collaborative student-centered learning environment in a wireless technology course. In Proceedings of the 39th IEEE international Conference on Frontiers in Education Conference. Piscataway, NJ: IEEE Press, 918-919.

[14] Safran, C. (2008). Blogging in higher education programming lectures: an empirical study. In Proceedings of the 12th interna- 
tional Conference on Entertainment and Media in the Ubiquitous. New York, NY: ACM, 131-135.

[15] Sarkar, S. (2009). Wiki-enhanced social scribing of lectures: a case study in an undergraduate course. In Proceedings of the 39th IEEE international Conference on Frontiers in Education Conference. Piscataway, NJ: IEEE Press, 1408-1413.

[16] Wheeler S (2009). Learning Space Mashups: Combining Web 2.0 Tools to Create Collaborative and Reflective Learning Spaces. Future Internet. 1(1), 3-13. doi:10.3390/fi1010003

[17] Xiao, Y., \& Lucking R. (2008). The impact of two types of peer assessment on students' performance and satisfaction within a Wiki environment. The Internet and Higher Education. 11(3-4), 186-193. doi:10.1016/j.iheduc.2008.06.005

[18] Xie, Y., Ke, F., \& Sharma, P. (2008) The effect of peer feedback for blogging on college students' reflective learning processes. The Internet and Higher Education. 11(1), 18-25. doi:10.1016/j.ihed uc.2007.11.001

\section{AUTHORS}

P. Grell is Professor in Department of Educational Science, University of Potsdam, Potsdam, 14476 Germany (e-mail: petra.grell@ uni-potsdam.de).

F. Rau is with the Department of Educational Science, University of Potsdam, Potsdam, 14476 Germany (e-mail: franco.rau@uni-potsdam.de).

This article was modified from a presentation at the International Conference of Interactive Computer Aided Learning ICL2010, September 2010 in Hasselt, Belgium.

Submitted September $28^{\text {th }}$, 2010. Published as resubmitted by the authors October 30 2010. 